\title{
Kelimpahan Fitoplankton Penyebab Harmful Algal Bloom di Perairan Desa Bedono, Demak
}

\author{
Lestari Febriant Pitaloka Gurning*, Ria Azizah Tri Nuraini, Suryono \\ Departemen IImu Kelautan, Fakultas Perikanan dan IImu Kelautan, Universitas Diponegoro \\ JI. Prof. H. Soedarto S.H, Tembalang, Semarang, Jawa Tengah 50275 Indonesia \\ ${ }^{*}$ Corresponding author, e-mail : lestarifebrian@gmail.com
}

\begin{abstract}
ABSTRAK: Fitoplankton adalah produsen primer yang struktur komunitasnya mudah berubah oleh perubahan sifat fisik, kimia (zat-zat hara) dan biologi ekosistemnya, sehingga keberadaan fitoplankton dalam suatu perairan bukan hanya dapat dijadikan parameter biologi dalam analisis status kualitas lingkungan perairan. Harmful Algal Bloom (HAB) merupakan fenomena yang sering terjadi di perairan laut. Definisi Harmful Algal Bloom (HAB) adalah pertambahan populasi fitoplankton yang dapat menimbulkan kerugian bagi ekosistem di sekitarnya, biota laut yang hidup didalamnya, maupun manusia yang hidup di wilayah pesisir. Keberadaan fitoplankton HAB di perairan desa Bedono dipicu oleh beberapa faktor, antara lain: suhu, salinitas, $D O, p H$, nitrat dan fosfat. Kelimpahan adalah pengukuran sederhana jumlah spesies yang terdapat dalam suatu komunitas. Pengamatan terhadap kelimpahan fitoplankton yang dapat menyebabkan HAB serta kaitannya dengan kandungan unsur hara dalam perairan sangat menentukan nilai ekonomis dan daya guna perairan sebagai sumber pangan. Penelitian ini bertujuan untuk melakukan identifikasi serta menghitung kelimpahan fitoplankton penyebab HAB di perairan desa Bedono, Demak. Penelitian ini dilakukan pada bulan Januari Tahun 2020. Metode yang digunakan dalam penelitian ini adalah metode survey yang bersifat eksploratif dan bertaraf deskriptif dengan tujuan untuk mengetahui gambaran suatu objek pengamatan dan dapat menjelaskan perkembangan yang terjadi pada kondisi pengamatan. Hasil dari penelitian ini ditemukan 2 kelas fitoplankton penyebab Harmful Algal Bloom (HAB), yaitu Bacillariophyceae dan Dinophyceae dengan 9 genus fitoplankton penyebab Harmful Algal Bloom (HAB). Kelimpahan fitoplankton penyebab Harmful Algal Bloom $(H A B)<2.000$ ind/L dimana termasuk kedalam kondisi kesuburan rendah (Oligotrofik). Parameter lingkungan seperti suhu, salinitas, $\mathrm{DO}, \mathrm{pH}$, nitrat dan fosfat. di perairan desa Bedono masih memenuhi batas optimum pertumbuhan fitoplankton.
\end{abstract}

Kata kunci: Fitoplankton; HAB; Mangrove; Bedono.

\section{Abundance phytoplankton causes Harmful Algal Bloom in the waters of Bedono village, Demak}

ABSTRACT: Phytoplankton is a primary manufacturer whose community structure is easily transformed by changes in physical, chemical (nutrient) properties and its ecological biology, so that the existence of phytoplankton in a water can not only be used as a biological parameter in the analysis of the quality status of aquatic environments. Harmful Algal Bloom (HAB) is a common phenomenon in marine waters. The definition of Harmful Algal Bloom (HAB) is the increase in the population of phytoplankton that can cause harm to surrounding ecosystems, marine life, and human beings living in coastal areas. The presence of HAB phytoplankton in Bedono village waters is triggered by several factors, such as: temperature, salinity, $\mathrm{DO}, \mathrm{pH}$, nitrate and phosphate. Abundance is a simple measurement of the number of species found in a community. Observations of the abundance of phytoplankton that can cause the HAB as well as its relation to nutrient content in the water determine the economical value and the power of the water as a food source. This research aims to identify and calculate the abundance of phytoplankton causes $H A B$ in the village waters of Bedono, Demak. The study was conducted in January 2020. The method used in this study is an exploratory and descriptive-grade survey method for the purpose of knowing the description of an object of observation and can explain the developments that occur in the observation condition. Results of this study found 2 classes of phytoplankton causes Harmful Algal Bloom (HAB), namely Bacillariophyceae and Dinophyceae with 9 genera of phytoplankton 
causes Harmful Algal Bloom (HAB). Abundance phytoplankton causes Harmful Algal Bloom (HAB) $<2,000 \mathrm{ind} / \mathrm{L}$ which is included in low fertility conditions (oligotrophic). Environmental parameters such as temperature, salinity, $\mathrm{DO}, \mathrm{pH}$, nitrate and phosphate. The waters of Bedono village still meet the optimum limit of the growth of phytoplankton.

Keywords: Phytoplankton; Environmental parameters; Mangrove; Bedono

\section{PENDAHULUAN}

Desa Bedono adalah kawasan pesisir dengan kondisi topografi yang landai dan datar. Desa Bedono yang terletak di topografi yang landai dan datar mudah mengalami kerusakan pantai, hal ini dapat terjadi akibat adanya erosi, adanya alih fungsi lahan dan adanya pencemaran yang masuk akibat adanya aktivitas manusia dan pabrik yang berada di wilayah Kabupaten Demak (Chafid et al., 2012). Salah satu cara yang dapat dilakukan untuk mengetahui kualitas di suatu perairan yaitu dengan mengetahui struktur komunitas fitoplankton (Hutami et al., 2017). Fitoplankton merupakan organisme mikroskopis yang mampu menghasilkan bahan organik dari bahan anorganik melalui proses fotosintesis dengan bantuan cahaya matahari (Wulandari et al., 2014). Keberadaan fitoplankton di suatu perairan dapat memberikan informasi mengenai kualitas perairan. Selain itu, fitoplankton dapat digunakan sebagai bioindikator suatu perairan untuk mengevaluasi kualitas dan kesuburan perairan (Hutami et al., 2017).

Umumnya fitoplankton di perairan Laut Jawa terdiri dari 4 kelas yaitu: Bacillariophyceae, Chlorophyceae, Cyanophycae dan Dinophyceae (Sari et al., 2014). Kelimpahan fitoplankton merupakan petunjuk dari kesuburan di suatu lingkungan perairan (Sofarini, 2012). Kategori perairan subur adalah apabila kelimpahan $>15.000$ ind/L (Aminah et al., 2020). Peningkatan populasi fitoplankton secara berlebihan dapat terjadi karena kondisi lingkungan perairan yang mendukung seperti peningkatan kadar nutrien. Ledakan populasi fitoplankton yang diikuti dengan keberadaan beberapa jenis fitoplankton beracun akan menyebabkan ledakan populasi alga berbahaya (Harmful Algal Bloom).

Harmful Algal Bloom (HAB) merupakan fenomena yang sering terjadi di perairan laut dikarenakan oleh pengkayaan unsur hara. Definisi Harmful Algal Bloom (HAB) adalah pertambahan populasi fitoplankton yang dapat menimbulkan kerugian bagi ekosistem di sekitarnya, biota laut yang hidup didalamnya, maupun manusia yang hidup di wilayah pesisir (Tungka et al., 2017). Keberadaan fitoplankton HAB di perairan dipicu oleh beberapa faktor. Salah satu faktor yang menyebabkan terjadinya blooming fitoplankton adalah pengkayaan unsur hara. Nutrien yang dominan mengakibatkan pengkayaan unsur hara adalah nitrat dan fosfat. Pengamatan terhadap kelimpahan fitoplankton yang dapat menyebabkan HAB serta kaitannya dengan kandungan unsur hara dalam perairan sangat menentukan nilai ekonomis dan daya guna perairan sebagai sumber pangan (Tungka et al., 2017). Oleh karena itu, penelitian ini adalah riset pendahuluan untuk melakukan identifikasi dan menghitung kelimpahan fitoplankton penyebab Harmful Algal Bloom (HAB) di perairan desa Bedono, Demak.

\section{MATERI DAN METODE}

Penelitian dilakukan pada bulan Januari 2020 di Perairan Desa Bedono Kabupaten Demak Jawa Tengah. Metode penelitian yang digunakan adalah metode survey yang bersifat eksploratif dan bertaraf deskriptif. Tujuan penelitian adalah untuk mengetahui kelimpahan fitoplankton yang dapat menyebabkan HAB di perairan desa Bedono, Demak. Penelitian bersifat eksploratif yaitu mempelajari fitoplankton secara menyeluruh pada waktu, tempat, dan populasi fitoplankton yang terbatas, sehingga memberikan gambaran tentang situasi dan kondisi secara lokal dan hasilnya tidak berlaku pada waktu dan tempat yang berbeda (Hutabarat et al., 2013). Teknik sampling yang digunakan adalah purposive sampling, yaitu pengambilan sampel dengan tujuan tertentu dari penelitian yang diharapkan sampel tersebut dapat mewakili populasi (Aminah et al., 2020).

Penelitian ini terbagi menjadi 3 stasiun dimana setiap stasiun terdiri dari 3 titik sampling (titik A, B, dan C). Dasar pertimbangan dalam penentuan stasiun adalah berdasarkan jarak dekat dan 
jauhnya dari ekosistem mangrove, adanya aktivitas manusia, serta adanya aliran sungai. Lokasi sampling berada pada perairan sekitar ekosistem mangrove. Stasiun yang dipilih untuk penelitian tersaji pada Gambar 1. Pengambilan sampel dilakukan pada bulan Januari tahun 2020. Pengambilan sampel dilakukan pengulangan sebanyak 3 kali pada masing-masing stasiun. Adapun stasiun-stasiun yang dipilih untuk penelitian yaitu: stasiun 1 sekitar ekosistem mangrove, stasiun 2 sekitar muara sungai, dan stasiun 3 laut lepas.

Sampel fitoplankton dikoleksi dengan metode aktif yaitu dengan menggunakan plankton net diameter $25 \mathrm{~cm}(60 \mu \mathrm{m})$ dan botol sampel. Plankton Net pada suatu titik di laut ditarik menuju ke titik lain pada permukaan perairan dengan jarak dan waktu tertentu menggunakan kapal dengan kecepatan kapal 1-2 knot atau setara dengan $1,852 \mathrm{~km} / \mathrm{jam}(0,514 \mathrm{~m} / \mathrm{s})$. Waktu yang dibutuhkan dalam sekali penyaringan dengan metode aktif yaitu \pm 5 menit. Sampel air untuk fitoplankton yang didapatkan dari masing-masing stasiun penelitian dengan 3 kali pengulangan diambil sebanyak $100 \mathrm{~L}$ dan dimasukkan kedalam botol sampel ukuran $100 \mathrm{ml}$ yang telah berisi formalin $4 \%$ sebanyak 3 tetes. Sampel yang diperoleh di dokumentasikan terlebih dahulu dengan menambahkan tagging bernomor pada setiap botol sampel sesuai titik (Sari et al., 2014).

Pengamatan jenis fitoplankton secara ex situ di laboratorium menggunakan sedgwick rafter counting cell dan mikroskop cahaya dengan perbesaran $10 \times 10$. Identifikasi fitoplankton penyebab $\mathrm{HAB}$ dilakukan dengan buku identifikasi. Parameter fisika-kimia perairan dilakukan pengukuran baik secara insitu maupun eksitu yaitu: suhu, salinitas, $\mathrm{pH}$, DO, kedalaman, dan kecerahan. Kelimpahan fitoplankton (individu per-liter) dihitung menurut Welch (1952) dalam (Afif et al., 2014). Sedangkan volume air yang tersaring dihitung menurut rumus Odum (1993) dalam (Aminah et al., 2020).

Menurut Nastiti dan Hartati (2016), kelimpahan individu fitoplankton dapat digolongkan berdasarkan 3 kategori, yaitu: Oligotrofik dimana perairan yang kesuburanya rendah dengan kelimpahan < 2.000 ind/L. Mesotrofik dimana perairan yang kesuburanya sedang dengan kelimpahan antara $2.000-15.000$ ind/L. Dan Eutrofik.dimana perairan yang kesuburanya tinggi dengan kelimpahan $>15.000$ ind/L.

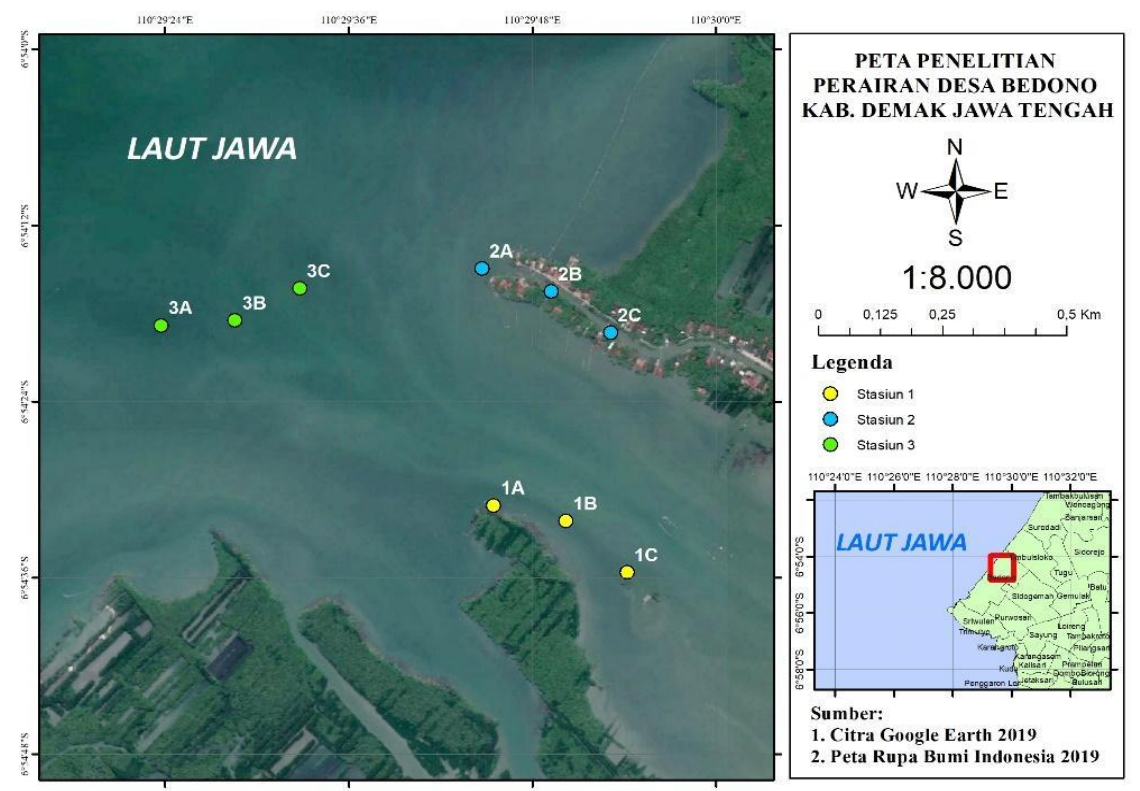

Gambar 1. Titik Sampling Lokasi Penelitian

\section{HASIL DAN PEMBAHASAN}

Hasil penelitian menunjukkan ditemukannyqa beberapa genus dari kelas Bacillariophyceae dan Dinophyceae yang berpotensi menyebabkan Harmful Algal Bloom (HAB). Gambar 2. Menjelaskan besarnya persentase kelas Bacillariophyceae yang berpotensi menyebabkan Harmful Algal Bloom (HAB) yaitu: sebesar 56\% (5 genus), sedangkan persentase kelas Dinophyceae yang 
berpotensi menyebabkan Harmful Algal Bloom (HAB) ditemukan sebesar 44\% (4 genus). Kelas Bacillariophyceae ditemukan sebanyak 5 genus fitoplankton penyebab HAB yaitu: Nitzschia, Pseudo Nitzschia, Thalassiosira, Chaetoceros dan Skeletonema. Sedangkan kelas Dinophyceae ditemukan sebanyak 4 genus fitoplankton penyebab HAB yaitu: Ceratium, Dinophysis, Protoperidinium dan Peridinium. Genus yang paling banyak ditemukan di Perairan desa Bedono adalah genus skeletonema, sedangkan genus yang paling sedikit ditemukan adalah Peridinium. Persentase komposisi fitoplankton penyebab Harmful Algal Bloom di Perairan Desa Bedono diperoleh hasil tertinggi yaitu Skeletonema dengan persentase sebesar $30 \%$. Sedangkan terendah yaitu Peridinium sebesar 3\%. Genus lainnya disajikan pada Gambar 3. Sedangkan komposisi fitoplankton penyebab Harmful Algal Bloom disajikan pada Tabel 1.

Hasil pengukuran parameter fisis dan khemis perairan didapatkan 8 parameter (Tabel 2). Parameter suhu berkisar antara $27-30^{\circ} \mathrm{C}$, suhu tertinggi terdapat pada stasiun 2 , sedangkan terendah terdapat pada stasiun 1. Parameter salinitas berkisar antara $20-27 \%$ o., salinitas tertinggi terdapat pada stasiun 3 , sedangkan terendah terdapat pada stasiun 2. Parameter $\mathrm{pH}$ berkisar antara $7-7.6, \mathrm{pH}$ tertinggi terdapat pada stasiun 3 , sedangkan terendah terdapat pada stasiun 2. Parameter oksigen terlarut berkisar antara $3.23-5.11 \mathrm{mg} / \mathrm{L}$, oksigen terlarut tertinggi terdapat pada stasiun 3, sedangkan terendah terdapat pada stasiun 2. Parameter kecerahan berkisar antara $18-25 \mathrm{~cm}$, kecerahan tertinggi terdapat pada stasiun 3 , sedangkan terendah terdapat pada stasiun 2. Kandungan nitrat di perairan berkisar antara 2,35 - 2,97 mg/L, nitrat tertinggi terdapat pada stasiun 1 dan nitrat terendah terdapat pada stasiun 3. Sedangkan kandungan fosfat di perairan berkisar antara $0,04-0,05 \mathrm{mg} / \mathrm{L}$, fosfat tertinggi terdapat pada stasiun 2 dan 3 dan fosfor terendah terdapat pada stasiun 1.

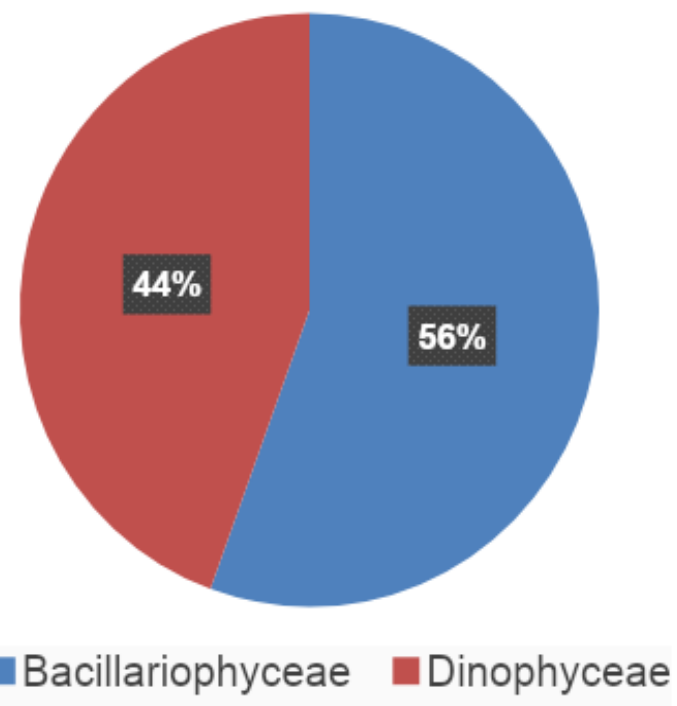

Gambar 2. Kelas Fitoplankton Penyebab HAB di Desa Bedono, Demak, Jawa Tengah

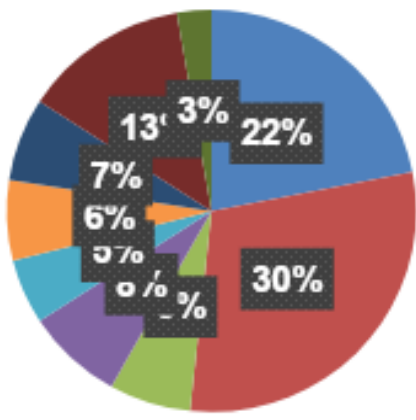

Nitzschia

Skeletonema

Pseudo Nitzschia
Protoperidinium

Ceratium

Peridinium

Gambar 3. Komposisi Fitoplankton Penyebab HAB di Desa Bedono, Demak, Jawa Tengah 
Tabel 1. Kelimpahan Fitoplankton Penyebab HAB yang telah di Identifikasi

\begin{tabular}{llcccc}
\hline \multirow{2}{*}{ Kelas } & & \multicolumn{3}{c}{ Stasiun } & \multirow{2}{*}{ Total } \\
\cline { 3 - 5 } & & 1 & 2 & 3 & \\
\hline Bacillariophyceae & Nitzschia & 185 & 397 & 806 & 1388 \\
& Skeletonema & 674 & 449 & 767 & 1890 \\
& Pseudo Nitzschia & 26 & 40 & 344 & 410 \\
& Thalassiosira & 198 & 145 & 145 & 488 \\
& Chaetoceros & 106 & 40 & 185 & 331 \\
Dinophyceae & Dinophysis & 26 & 0 & 383 & 409 \\
& Protoperidinium & 106 & 185 & 132 & 423 \\
& Ceratium & 172 & 317 & 344 & 833 \\
& Peridinium & 0 & 0 & 172 & 172 \\
\hline
\end{tabular}

Hasil identifikasi, fitoplankton penyebab HAB yang ditemukan di perairan desa Bedono hanya terdapat 2 kelas. Kelas Bacillariophyceae merupakan kelas yang paling banyak terdapat fitoplankton penyebab Harmful Algal Bloom (HAB), hal ini disebabkan karena kelas Bacillariophyceae memiliki tingkat kemampuan pertumbuhan yang relatif cepat bahkan pada kondisi lingkungan yang kurang menguntungkan sekalipun. Sehingga, kelompok ini merupakan komponen fitoplankton yang paling umum dijumpai di laut dan terdapat di semua area, dari tepi pantai hingga ke tengah samudera (Putri et al., 2019). Sedangkan kelas Dinophyceae merupakan kelas terbanyak kedua fitoplankton penyebab HAB.

Seperti yang diungkapkan oleh Rashidy et al. (2013), di perairan Indonesia memperlihatkan kecenderungan dominasi Diatom dan Dinoflagellata dalam komposisi fitoplankton. Sehingga dalam identifikasi, hanya ditemukan dari diatom dan dinoflagellata yang dapat menyebabkan HAB. Selama identifikasi ditemukan beberapa genus fitoplankton yang cukup berbahaya di perairan desa Bedono, yaitu: Pseudonitzschia, Nitzschia, Skeletonema, Thalassiosira, Chaetoceros, Ceratium, Dinophysis, Protoperidinium dan Peridinium. Berdasarkan hasil identifikasi, genus Skeletonema merupakan genus dengan kelimpahan tertinggi yang ditemukan di perairan desa Bedono, sedangkan genus Peridinium merupakan genus dengan kelimpahan terendah selama penelitian.

Skeletonema merupakan fitoplankton berbahaya yang menyebabkan hypoxia dan anoxia jika dikonsumsi. Apabila spesies ini blooming maka dapat menyumbat alat pernapasan dan menyebabkan kematian massal pada biota perairan. Kepadatan total Skeletonema yaitu 1.890 Ind/L. Alga dikatakan blooming apabila perbandingan konsentrasi alga mencapai ribuan hingga $10^{6}$ Ind/L. Meski tidak blooming, namun Skeletonema berpotensi menyebabkan Harmful Algae Blooms (HABs). Hal ini perlu diwaspadai sebab Skeletonema dapat menyebabkan kematian massal pada ikan (Mulyani et al., 2012).

Chaetoceros adalah jenis mikroalga yang umumnya paling banyak di perairan laut. Jenis ini tergolong kedalam kelas Bacillariophyceae (Diatom). Kepadatan total Chaetoceros yaitu $331 \mathrm{Ind} / \mathrm{L}$. Alga dikatakan blooming apabila perbandingan konsentrasi alga mencapai ribuan hingga $10^{6} \mathrm{Ind} / \mathrm{L}$. Chaetoceros tidak menghasilkan racun (toxin) namun ketika terjadi blooming, alga jenis ini memiliki efek yaitu dapat menyebabkan terjadinya iritasi yang merangsang pembentukan lendir pada insang ikan sehingga dapat membuat ikan menjadi susah untuk bernafas dan akhirnya mati (Choirun et al., 2015).

Ceratium adalah mikroalga laut bersel tunggal yang tergolong dalam kelas Dinophyceae. Ceratium merupakan organisme heterotrof yang mampu bermigrasi secara vertikal dari permukaan ke bawah pada kolom perairan dan bersifat kosmopolit. Kepadatan total Ceratium yaitu 833 Ind/L. Alga dikatakan blooming apabila perbandingan konsentrasi alga mencapai ribuan hingga $10^{6} \mathrm{Ind} / \mathrm{L}$. Genus ini tidak menghasilkan toksin, namun ketika terjadi blooming, jenis ini dapat mengakibatkan kematian massal organisme laut dan dapat menyebabkan red tide jika kondisi lingkungan perairannya dapat mendukung dalam pertumbuhannya (Tungka et al., 2016). 
Tabel 2. Pengukuran Parameter Perairan yang telah di Identifikasi dari Perairan Desa Bedono Kabupaten Demak, Jawa Tengah

\begin{tabular}{|c|c|c|c|c|c|}
\hline \multirow{2}{*}{ Parameter } & \multicolumn{3}{|c|}{ Stasiun } & \multirow{2}{*}{$\begin{array}{c}\text { Optimum } \\
\text { Fitoplankton }\end{array}$} & \multirow{2}{*}{ Sumber } \\
\hline & 1 & 2 & 3 & & \\
\hline Suhu $\left(\mathrm{C}^{\circ}\right)$ & 27 & 30 & 29 & $20-30$ & (Sofarini, 2012) \\
\hline Salinitas (\%o) & 25 & 20 & 27 & $25-32$ & (Faturohman et al., 2016) \\
\hline Kecerahan $(\mathrm{cm})$ & 21 & 18 & 25 & $0-250$ & (Aminah et al., 2020). \\
\hline $\mathrm{DO}(\mathrm{mg} / \mathrm{L})$ & 4.51 & 3.23 & 5.11 & $1-6$ & (Widiana, 2012) \\
\hline $\mathrm{pH}$ & 7.2 & 7 & 7.6 & $6.5-8$ & (Widiana, 2012) \\
\hline Nitrat (mg/L) ${ }^{1}$ & 2.97 & 2.86 & 2.35 & $0.9-3.5$ & (Permatasari et al., 2016) \\
\hline Phospat $(\mathrm{mg} / \mathrm{L})^{2}$ & 0.04 & 0.05 & 0.05 & $0.09-1.8$ & (Permatasari et al., 2016) \\
\hline
\end{tabular}

Sumber $^{182}$ : Aufa Rifqi Widiardja (2020)

Dinophysis merupakan fitoplankton air laut dari kelas Dinophyceae. Dinophysis bereproduksi secara aseksual melalui pembelahan sel secara biner. Distribusinya dapat ditemukan hampir di seluruh dunia baik di negara beriklim temperate maupun tropis. Dinophysis termasuk salah satu genus yang mampu memproduksi toksin dari jenis dinophysis toxins (DTXs) dan okadaic acid (OA). Toksin tersebut dapat menyebabkan manusia mengalami keracunan yang disebut Diarrhetic Shellfish Poisoning (Barokah et al., 2017). Kepadatan total Dinophysis yaitu 409 Ind/L. Alga dikatakan blooming apabila perbandingan konsentrasi alga mencapai ribuan hingga $10^{6} \mathrm{Ind} / \mathrm{L}$.

Protoperidinium adalah organisme bersel tunggal termasuk dalam kelompok armoured dinoflagellate. Protoperidinium tergolong dalam kelas Dinophyceae. Spesies ini dapat ditemukan pada semua area laut yang memiliki iklim temperate maupun topis. Protoperidinium tidak memproduksi toksin, tetapi dapat mengandung toksin karena mengkonsumsi spesies dinoflagellata beracun yang lain, yang disebut Azadinium. Tingginya konsentrasi Protoperidinium dapat menyebabkan oxygen depletion di sebuah perairan (Choirun et al., 2015). Kepadatan total Protoperidinium yaitu $409 \mathrm{Ind} / \mathrm{L}$. Alga dikatakan blooming apabila perbandingan konsentrasi alga mencapai ribuan hingga $10^{6} \mathrm{Ind} / \mathrm{L}$.

Nitzschia dan Pseudo-nitzschiamerupakan fitoplankton yang menghasilkan toksin asam domoic yang dapat memasuki rantai makanan hingga ke tubuh manusia melalui perantara kerang. Toksin asam domoic adalah racun saraf yang menyebabkan gangguan gastroenteritis dan neurological (Choirun et al., 2015). Nitzschia dan Pseudo-nitzschia adalah genus yang dapat menyebabkan ASP (Amnesic Shellfish Poisoning). Kepadatan total Nitzschia dan PseudoNitzschia yaitu 1.388 Ind/L dan 410 Ind/L. Alga dikatakan blooming apabila perbandingan konsentrasi alga mencapai ribuan hingga $10^{6} \mathrm{Ind} / \mathrm{L}$.

Genus Peridinium dapat menyebabkan Red tide, toksik pada biota, serta reduksi kualitas air (Barokah et al., 2017). Kepadatan total Peridinium yaitu 172 Ind/L. Alga dikatakan blooming apabila perbandingan konsentrasi alga mencapai ribuan hingga $10^{6}$ Ind/L.Tabel 1 menjelaskan bahwa kelimpahan fitoplankton penyebab HAB tertinggi terdapat pada stasiun 3 sedangkan terendah terdapat pada stasiun 1. Hal ini diduga karena pada stasiun 3 terjadi proses upwelling yang merupakan peristiwa teraduknya air. Adanya upwelling dapat mempengaruhi nutrien yang berada pada perairan tersebut. Selain itu, perbedaan kelimpahan fitoplankton penyebab HAB pada setiap stasiun diduga karena kondisi lingkungan yang terdapat pada setiap stasiun berbeda-beda. Kondisi lingkungan perairan meliputi Suhu, Salinitas, pH, DO, Kecerahan, dan Musim. Sedangkan salah satu faktor pembatas yang dapat mempengaruhi kelimpahan fitoplankton adalah Nitrat dan Fosfat.

Nitrat $(\mathrm{N})$ dan fosfat $(\mathrm{P})$ merupakan unsur yang dibutuhkan oleh fitoplankton untuk pertumbuhan. Nitrat dan fosfat dimanfaatkan oleh fitoplankton sebagai bahan dasar pembuatan bahan organik yang digunakan sebagai sumber makanan primer di rantai makanan dengan bantuan cahaya matahari. Namun konsentrasi nitrat dan fosfat yang dimanfaatkan fitoplankton memiliki batas tertentu, konsentrasi nitrat dan fosfat yang melebihi batas yang dimanfaatkan dapat memicu peristiwa pengkayaan nutrien atau yang lebih dikenal dengan eutrofikasi (Hamuna et al., 2018). Berdasarkan hasil analisis, konsentrasi kandungan nitrat di perairan desa Bedono berkisar 
antara 2,35 - 2,97 mg/L. Kandungan nitrat tertinggi berada pada stasiun 1, sedangkan terendah terdapat pada stasiun 3. Menurut Permatasari et al. (2016), kandungan optimum nitrat di perairan untuk pertumbuhan fitoplankton berkisar antara 0,9-3,5 $\mathrm{mg} / \mathrm{L}$. Berdasarkan hasil yang diperoleh, kandungan nitrat di perairan desa Bedono masih memenuhi standar optimum nitrat untuk pertumbuhan fitoplankton (tidak lebih dari $3,5 \mathrm{mg} / \mathrm{L}$ ).

Kandungan nitrat tertinggi berada pada stasiun 1 dengan kelimpahan $1.493 \mathrm{Ind} / \mathrm{L}$. Sedangkan kandungan nitrat rendah berada pada stasiun 3 dengan kelimpahan sebesar 3.278 Ind/L. Berdasarkan hasil, dapat dikatakan bahwa kandungan nitrat yang tinggi di suatu perairan tidak menghasilkan kelimpahan yang tinggi, sedangkan kandungan nitrat yang rendah dapat menghasilkan kelimpahan yang tinggi. Hal ini didasari karena nitrat di suatu perairan hanya sebagai faktor pembatas, dimana kandungan yang tinggi tidak membuat kelimpahan semakin tinggi. Pendapat ini diperkuat oleh Rumanti et al. (2014), bahwa kandungan nitrat yang optimum bagi pertumbuhan fitoplankton antara kurang dari 3,5. Sehingga jika semakin tinggi kandungan nitrat maka dapat menyebabkan peristiwa pengkayaan nutrisi (eutrofikasi). Besarnya kandungan nitrat di perairan desa Bedono disebabkan oleh perbedaan ekosistem setiap pengambilan sampel.

Besarnya kandungan nitrat pada stasiun 1 dan disebabkan karena adanya masukan dari serasah mangrove. Stasiun 1 merupakan ekosistem mangrove dimana mangrove memiliki berasal dari serasah mangrove. Sedangkan stasiun 3 merupakan laut lepas yang berjarak cukup jauh dari wilayah pesisir, sehingga memiliki konsentrasi nitrat yang lebih rendah dibandingkan stasiun lainnya. Tingginya konsentrasi nitrat di perairan desa Bedono dapat disebabkan oleh masukan bahan organik yang tinggi dari aktivitas daratan yang dapat berupa erosi daratan, masukan limbah rumah tangga, dan limbah industri yang terbawa ke perairan laut.

Konsentrasi fosfat di perairan desa Bedono berkisar antara 0,04 - 0,05 mg/L. Kandungan fosfat tertinggi terdapat pada stasiun 3 sedangkan terendah terdapat pada stasiun 1 . Menurut Permatasari et al. (2016), kandungan optimum fosfat diperairan untuk pertumbuhan fitoplankton berkisar antara 0,09-1,8 mg/L, sehingga dapat dikatakan bahwa kandungan fosfat di perairan desa Bedono masih memenuhi standar optimum pertumbuhan fitoplankton. Pendapat ini diperkuat oleh Hamuna et al. (2018), bahwa tingkat maksimum fosfat yang disarankan untuk sungai dan perairan yang telah dilaporkan adalah $0,1 \mathrm{mg} / \mathrm{L}$.

Terdapat hubungan antara kelimpahan fitoplankton dengan kandungan fosfat di suatu perairan. Tabel 2 menjelaskan bahwa kandungan fosfat di perairan desa Bedono tidak terpaut jauh. Stasiun 2 dan 3 memiliki nilai fosfat yang sama, sedangkan stasiun 1 memiliki nilai fosfat yang tidak jauh beda dengan stasiun 2 dan stasiun 3. Berdasarkan hasil yang telah diperoleh, maka dapat dikatakan bahwa kandungan fosfat tinggi dapat mempengaruhi kelimpahan fitoplankton di suatu perairan. Pendapat ini diperkuat oleh Aminah et al. (2020), bahwa kandungan fosfat antara 0,051 - 0,100 termasuk kedalam kesuburan yang baik, sedangkan kandungan fosfat $<0,051$ termasuk kedalam kesuburan yang cukup.

Sehingga dapat dikatakan bahwa tingginya kandungan fosfat di suatu perairan menandakan kesuburan yang baik untuk pertumbuhan fitoplankton. Menurut Hamuna et al. (2018), senyawa fosfat di perairan berasal dari sumber alami seperti erosi tanah, buangan dari hewan dan pelapukan tumbuhan. Konsentrasi meningkat dengan masuknya limbah domestik, industri dan pertanian atau perkebunan yang banyak mengandung fosfat, hancuran bahan organik dan mineral-mineral fosfat. Selain hubungan antara kelimpahan dengan nitrat dan fosfat, kelimpahan fitoplankton penyebab HAB juga dipengaruhi oleh kondisi perairan pada saat pengambilan sampel. Kondisi perairan tersebut meliputi suhu, DO, salinitas, ph, dan kecerahan. Kondisi perairan ini disebut juga sebagai parameter perairan yang dapat mempengaruhi pertumbuhan fitoplankton di dalam perairan.

Suhu memegang peranan penting dalam menentukan keberadaan fitoplankton dalam perairan. Suhu dapat mempengaruhi laju fotosintesis secara langsung maupun tidak langsung (Hamuna et al., 2018). Suhu pada daerah penelitian berkisar antara $27-30^{\circ} \mathrm{C}$. Suhu tertinggi terdapat pada stasiun 2, sedangkan suhu terendah terdapat pada stasiun 1 . Tinggi rendahnya suhu dipengaruhi oleh waktu pengambilan sampel. Berdasarkan baku mutu perairan air laut untuk biota laut dalam Keputusan Menteri Negara Lingkungan Hidup No. 51 tahun 2004, suhu yang terdapat di perairan desa Bedono masih memenuhi syarat untuk pertumbuhan dan perkembangan 
fitoplankton. Hal ini diperkuat oleh Sofarini (2012), bahwa suhu optimum pada pertumbuhan fitoplankton berkisar antara $20-35^{\circ} \mathrm{C}$.

Kandungan DO pada suatu perairan sangat berhubungan dengan tingkat pencemaran, jenis limbah, dan banyaknya bahan organik di suatu perairan. Kandungan DO di sekitar perairan desa Bedono berkisar antara 3,23 - 5.11 mg/L. Kandungan oksigen terlarut (DO) terendah terdapat pada stasiun 2, sedangkan tertinggi terdapat pada stasiun 3. Rendahnya nilai DO di stasiun 2 menandakan bahwa proses fotosintesis yang terjadi kurang maksimal, hal ini disebabkan karena rendahnya nilai kecerahan dimana kurang dari $30 \mathrm{~cm}$, sehingga penetrasi cahaya tidak dapat mencapai ke perairan yang dalam. Menurut Nybakken (1992) dalam Widiana (2012), bahwa kandungan DO optimum untuk pertumbuhan fitoplankton berkisar antara $1-6 \mathrm{mg} / \mathrm{L}$, hal ini didukung oleh pendapat Subarijanti (2005) dalam Hamuna et al. (2018), bahwa kandungan oksigen dalam air yang ideal adalah antara $3-7 \mathrm{mg} / \mathrm{l}$. Sehingga berdasarkan pernyataan diatas maka dapat dikatakan bahwa kandungan oksigen terlarut (DO) di perairan desa Bedono tergolong optimum untuk pertumbuhan fitoplankton.

Salinitas merupakan konsentrasi seluruh larutan garam yang diperoleh dalam air laut, dimana salinitas air berpengaruh terhadap tekanan osmotik air, semakin tinggi salinitas maka akan semakin tinggi tekanan osmotiknya (Hamuna et al., 2018). Hasil pengukuran salinitas di perairan desa Bedono saat surut berkisar antara 20 - 27 \%o. Menurut Nybakken (1992) dalam Faturohman et al. (2016), bahwa kandungan optimum salinitas untuk pertumbuhan fitoplankton berkisar antara 25 - $32 \%$. Hasil yang diperoleh menunjukkan bahwa pada stasiun 2 memiliki salinitas yang rendah. Rendahnya salinitas pada stasiun 2 disebabkan karena adanya suplai air tawar melalui aliran sungai yang bermuara di perairan laut. Seperti yang diungkapkan oleh Hamuna et al. (2018), bahwa daerah estuaria adalah daerah dimana kadar salinitasnya berkurang karena adanya pengaruh air tawar yang masuk dan juga disebabkan oleh terjadinya pasang surut di daerah itu.

Derajat keasaman $(\mathrm{pH})$ merupakan suatu indikator baik buruknya suatu perairan. $\mathrm{pH}$ suatu perairan merupakan salah satu parameter kimia yang cukup penting dalam memantau kestabilan perairan. Pada fitoplankton nilai $\mathrm{pH}$ sangat menentukan dominansi fitoplankton serta mempengaruhi tingkat produktivitas primer suatu perairan (Hamuna et al., 2018). Hasil pengukuran $\mathrm{pH}$ di sekitar perairan desa Bedono berkisar 7-7,6. Menurut Nybakken (1992) dalam Widiana (2012), bahwa pH optimum untuk pertumbuhan fitoplankton berkisar antara 6,5-8. Sehingga berdasarkan pernyataan diatas maka dapat dikatakan bahwa $\mathrm{pH}$ di perairan desa Bedono tergolong optimum untuk pertumbuhan fitoplankton karena termasuk kedalam kategori basa, dimana kondisi basa merupakan habitat maksimum dalam pertumbuhan fitoplankton (Aminah et al., 2020).

Kecerahan merupakan tingkat transparansi perairan yang dapat diamati secara visual. Kecerahan menunjukkan adanya kemampuan intensitas cahaya matahari untuk menembus suatu perairan. Berdasarkan hasil yang telah diperoleh, nilai kecerahan berkisar antara $18-25 \mathrm{~cm}$. Stasiun 2 merupakan stasiun dengan nilai kecerahan rendah, hal ini dikarenakan stasiun 2 merupakan muara sungai yang memiliki banyak suplai sedimen dan partikel yang terlarut, bahan organik dan anorganik melalui aliran run off dari daratan dan menyebabkan tingkat kekeruhan perairan yang tinggi. Menurut Sofarini (2012), nilai kecerahan yang baik bagi kelangsungan hidup organisme perairan adalah $>45 \mathrm{~cm}$, maka nilai kecerahan di perairan desa Bedono pada saat surut memiliki kecerahan yang kurang baik bagi pertumbuhan fitoplankton.

Selain faktor diatas, salah satu faktor yang dapat mempengaruhi kelimpahan fitoplankton penyebab HAB di perairan desa Bedono adalah musim. Pada musim hujan konsentrasi nutrien akan lebih rendah dibandingkan dengan musim kemarau sehingga densitas fitoplankton juga rendah. Kondisi ini disebabkan karena pada saat musim penghujan, kadar curah hujan yang tinggi memiliki penetrasi cahaya, salinitas, suhu yang rendah, serta kekeruhan yang tinggi dibanding musim kemarau. Tinggi rendahnya kelimpahan fitoplankton penyebab HAB di musim hujan dikaitkan dengan interaksi alga dan unsur hara (Nirmalasari et al., 2016). Berdasarkan hasil analisis kelimpahan fitoplankton di setiap stasiun di perairan desa Bedono maka dapat diketahui pola persebaran fitoplankton di perairan desa Bedono mengalami persebaran yang tidak merata dan cenderung mengikuti arah Arus.

Identifikasi fitoplankton penyebab HAB pada penelitian ini hanya sampai tingkat genus, sehingga tidak sepenuhnya genus yang sudah disebutkan diatas berbahaya, karena hanya 
beberapa spesies yang terdapat pada genus tersebut yang berbahaya. Genus yang berhasil diidentifikasi menunjukan kelimpahan yang kurang dari 5.000 Ind/L dan tidak mendominasi. Perairan dikatakan blooming jika jumlah kelimpahan fitoplankton penyebab blooming mencapai jutaan Ind/L. Blooming juga dapat terjadi ketika jumlah kelimpahan yang naik secara drastis (Eksponensial) dan berlangsung selama kurun waktu 1-2 minggu. Pemicu terjadinya blooming adalah peningkatan kadar nutrien sehingga terjadinya eutrofikasi (penyuburan) pada perairan.

\section{KESIMPULAN}

Hasil identifikasi ditemukan beberapa genus fitoplankton yang cukup berbahaya di perairan desa Bedono, yaitu: Pseudo Nitzschia, Nitzschia, Skeletonema, Thalassiosira, Chaetoceros, Ceratium, Dinophysis, Protoperidinium dan Peridinium.Genus Skeletonema adalah genus dengan kelimpahan tertinggi, sedangkan genus Peridinium merupakan genus dengan kelimpahan terendah. Kelimpahan fitoplankton yang dapat menyebabkan HAB termasuk dalam kategori Oligotrofik (kurang dari 2.000 Ind.L), sehingga dapat disimpulkan bahwa kesuburan perairan desa Bedono adalah rendah. Parameter lingkungan di perairan desa Bedono masih memenuhi batas optimum pertumbuhan fitoplankton.

\section{UCAPAN TERIMAKASIH}

Artikel ini adalah bagian dari skripsi dengan judul "Struktur Komunitas Fitoplankton di Perairan Sekitar Ekosistem Mangrove Desa Bedono, Demak." untuk memperoleh gelar sarjana Strata Satu pada Departemen IImu Kelautan Fakultas Perikanan dan IImu Kelautan Universitas Diponegoro.

\section{DAFTAR PUSTAKA}

Afif, A., Widianingsih, \& Retno, H. 2014. Komposisi Dan Kelimpahan Plankton Di Perairan Pulau Gusung Kepulauan Selayar Sulawesi Selatan. Journal of Marine Research, 3(3):324-331.DOI: 10.14710/jmr.v3i3.6004.

Aminah, S., Nuraini, R.A.T., \& Djunaedi, A. 2020. Komposisi dan Kelimpahan Fitoplankton di Perairan Pandansari, Desa Kaliwlingi Kabupaten Brebes, Jawa Tengah. Journal of Marine Research, 9(1): 81-86. DOI: 10.14710/jmr.v9i1.25793.

Barokah, G.R., Putri, A.K., \& Gunawan, G. 2017. Kelimpahan Fitoplankton Penyebab HAB (Harmful Algal Bloom) di Perairan Teluk Lampung pada Musim Barat dan Timur. Jurnal Pascapanen Dan Bioteknologi Kelautan dan Perikanan, 11(2): 115. DOI: 10.15578/jpbkp.v11i2.302.

Choirun, A., Sari, S.H.J., \& Iranawati, F. 2015. Identifikasi Fitoplankton Spesies HAB Saat Kondiis Pasang di Perairan Pesisir Brondong, Lamongan, Jawa Timur. Jurnal IImu Kelautan Dan Perikanan, 25(2): 56-66. DOI: 10.1017/CBO9781107415324.004.

Faturohman, I., Sunarto \& Isni, N. 2016. Korelasi Kelimpahan Plankton Dengan Suhu Perairan Laut Di Sekitar PLTU Cirebon. Jurnal Perikanan Kelautan, 7(1):115-122

Hamuna, B., Tanjung, R.H.R., Suwito, Maury, H.K., \& Alianto. 2018. Kajian Kualitas Air Laut dan Indeks Pencemaran Berdasarkan Parameter Fisika-Kimia di Perairan Distrik Depapre, Jayapura. Jurnal Ilmu Lingkungan, 16(1):35-43. DOI: 10.14710/jil.16.1.35-43.

Hutabara, S., Prijadi S., \& Ina C. 2013. Studi Analisa Plankton untuk Menentukan Tingkat Pencemaran di Muara Sungai Babon Semarang. Journal of Management of Aquatic Resources, 2(3):74-84.

Mulyani, M., Widiarti, R., \& Wardhana, W. 2012. Sebaran Spasial Spesies Penyebab Harmful Algal Bloom (HAB) di Lokasi Budidaya Kerang Hijau (Perna viridis) Kamal Muara, Jakarta Utara pada Bulan Mei 2011. Jurnal Akuatika Indonesia, 3(1):28-39.

Nastiti, A.S., \& Hartati, S.T. 2016. Struktur Komunitas Plankton dan Kondiis Lingkungan Perairan di Teluk Jakarta. Jurnal BAWAL Widya Riset Perikanan Tangkap, 5(1):131-150. DOI: 10.15578/bawal.5.3.2013.131-150.

Nirmalasari, K.P., Lukitasari, M., \& Widianto, J. 2016. Pengaruh Intensitas Musim Hujan Terhadap 
Kelimpahan Fitoplankton Di Waduk Bening Saradan. Jurnal Edukasi Matematika Dan Sains, 2(1):41-47. DOI: 10.25273/jems.v2i1.178.

Permatasari, R.D., Djuwito \& Irwani. 2016. Pengaruh Kandungan Nitrat dan Fosfat Terhadap Kelimpahan Diatom di Muara Sungai Wulan, Demak. Diponegoro Journal of Maquares, $5(4): 224-232$.

Putri, C.R., Djunaedi, A., \& Subagyo, S. 2019. Ekologi Fitoplankton: Ditinjau dari Aspek Komposisi, Kelimpahan, Distribusi, Struktur Komunitas dan Indeks Saprobitas Di Perairan Morosari, Demak. Journal of Marine Research, 8(2):197-203. DOI: 10.14710/jmr.v8i2.25103.

Rashidy, E.A., Litaay, M., Salam, M.A., \& Umar, M.R. 2014. Komposisi Dan Kelimpahan Fitoplankton Di Perairan Pantai Kelurahan Tekolabbua, Kecamatan Pangkajene, Kabupaten Pangkep, Provinsi Sulawesi Selatan. Jurnal Alam Dan Lingkungan, 4(7):12-16.

Sari, A. N., Hutabarat, S., \& Soedarsono, P. 2014. Struktur Komunitas Plankton pada Padang Lamun di Pantai Pulau Panjang, Jepara. Management of Aquatic Resources Journal, 3(2):8291.

Sofarini, D. 2012. Keberadaan dan Kelimpahan Fitoplankton Sebagai Salah Satu Indikator Kesuburan Lingkungan Perairan di Waduk Riam Kanan. Enviro Scienteae, 8(1):30-34.

Tungka, A. W., Haeruddin, \& Ain, C. 2016. Konsenrasi Nitrat dan Ortofosfat di Muara Sungai Banjir Kanal Barat dan Kaitannya dengan Kelimpahan Fitoplankton HABs. Saintek Perikanan: Indonesian Journal of Fisheries Science and Technology, 12(1):40-46. DOI: 10.14710/ijfst.12.1.

Wulandari, D.Y., Tunjung, N., Pratiwi, M., \& Adiwilaga, E.M. 2014. Distribusi Spasial Fitoplankton di Perairan Pesisir Tangerang. Jurnal IImu Pertanian Indonesia, 19(3):156-162 